\title{
Liber и libertas в произведениях Горация
}

\author{
Д.А. Усов \\ Ярославский государственный университет им. П.Г. Демидова, \\ Россия, 150003, Ярославль, ул. Советская, 14/2 \\ E-mail: usovda1996@gmail.com
}

\begin{abstract}
Аннотация. Статья посвящена изучению категории «свобода» в произведениях Горация. Во времена Поздней Республики термин «libertas» использовался различными политическими партиями (partes) и группировками (factiones) как инструмент идеологической борьбы со своими противниками. Данное обстоятельство должно было повлиять на восприятие свободы в эпоху Августа. Предпринятый в статье анализ терминов «liber» и «libertas» у Горация направлен на постижение вложенного в них смысла, а также на определение политических взглядов поэта. Наблюдения автора свидетельствуют, что Гораций не обращался к данным терминам в том значении, которое в них вкладывали те или иные политические силы Поздней Республики. Восприятие свободы поэтом находилось в русле идеологической политики Августа и не несло в себе оппозиционных настроений.
\end{abstract}

Ключевые слова: античный Рим, принципат Августа, Октавиан (Август), Гораций, свобода, liber, libertas.

Для цитирования: Усов Д.А. 2020. Liber и libertas в произведениях Горация. Via in tempore. История. Политология, 47 (3): 472-481. DOI 10.18413/2687-0967-2020-47-3-472-481.

\section{Liber and libertas in Horace's works}

\author{
Dmitry A. Usov \\ Yaroslavl State University P.G. Demidov, \\ 14/2 Sovetskaya St., Yaroslavl, 150003, Russia \\ E-mail: usovda1996@gmail.com
}

\begin{abstract}
The article is devoted to the study of the category «freedom» in Horace's works. In the days of the Late Republic, various political parties (partes) and groups (factiones) used the term «libertas» as an instrument of ideological struggle against their opponents. Besides, each political force attached a special meaning to this concept, which correlated with their goals and ideological discourse. This fact should have affected the perception of freedom in the times of Augustus' reign. The author undertakes the analysis of the terms «liber» and «libertas» used by Horace with the aim to comprehend their meaning, as well as determine political views of the poet. The author's observations demonstrate the predominance of the social and philosophical connotations of the concepts «liber» and «libertas» in Horace's works. The conclusions made in the article show that the poet did not refer to these terms in the sense certain political forces of the Late Republic attached to them. Horace's perception of freedom was congruent with the ideological policy of Augustus and did not contain any opposition sentiment.
\end{abstract}

Keywords: Ancient Rome, Augustus' Principate, Octavian (Augustus), Horace, freedom, liber, libertas.

For citation: Usov D.A. 2020. Liber and libertas in Horace's works. Via in tempore. History and political science, 47 (3): 472-481 (in Russian). DOI 10.18413/2687-0967-2020-47-3-472-481.

Общество воспринимает реальность с помощью различных мыслительных категорий; как заметил А.Я. Гуревич [Гуревич, 2007, с. 35-36], такие категории отражают общественную практику и вместе с тем определяют поведение индивидов и групп. 


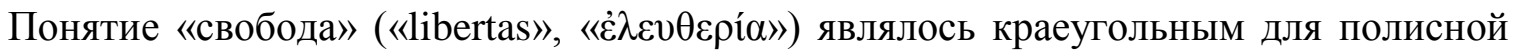
цивилизации [Дементьева, 2010, с. 89]. Латинский термин «libertas», обладая изначально социальной коннотацией, обозначал личную свободу, которая противопоставлялась рабству (servitus). Однако впоследствии (к V в. до н. э.) данная категория приобрела и политический смысл. Libertas воплотила один из принципов внутриполитической жизни Римской республики [Межерицкий, 2016, с. 490] и общую для всего гражданского коллектива ценность [Дементьева, 2011, с. 147-148; Arena, 2012, p. 14]- политическую свободу. Более того, свобода являлась одной из первых персонифицированных абстракций, почитаемых в Риме как божество, - Libertas [Von der Osten, 2006, p. 32].

Важным источником для изучения понимания libertas в эпоху правления Августа (27 г. до н. э. - 14 г. н. э.) являются поэтические произведения данного периода, а также более раннего - времени борьбы Октавиана за власть. Помимо того, что восприятие свободы известными авторами может свидетельствовать о месте libertas в идеологии Принципата ${ }^{3}$, оно также указывает на отношение поэтов к режиму Августа и проясняет широкие общественные настроения ${ }^{4}$. В рамках данной статьи мы сосредоточимся на анализе категории «libertas» (и исходного понятия «liber») в произведениях Горация.

Нами не было обнаружено ни одного специального исследования по указанному вопросу, хотя некоторые историки в той или иной степени его касались. К примеру, Ч. Старр, рассматривая развитие отношения Горация к Августу ${ }^{5}$, отметил, что поэт, склонный в зрелом возрасте к аристократической морали, использовал понятия «liber» и «libertas» в социальном, а не политическом значении [Starr, 1969, p. 62-64]. Некоторых аспектов восприятия Горацием свободы коснулся У.С. Андерсон [Anderson, 1995, p. 163-164]. Влияние греческой этики на понимание Горацием дружбы (amicitia) и «свободы слова» (одной из составляющих libertas) рассмотрел Р.Л. Хантер [Hunter, 1985]. Л. Боудич подробно остановилась на анализе выражения «liberrimus Lollius», использованном поэтом в одном из своих посланий [Bowditch, 1994]. О «свободе слова» в рамках римской сатиры пишет С.M. Браунд [Braund, 2004].

При этом многие ученые так или иначе обращались к анализу libertas в произведениях Вергилия и Овидия [Lefèvre, 1998, p. 103-106; Galinsky, 2006; Johnston, 2006; Smith, 2006; Von der Osten, 2006; McGowan, 2009, p. 175; Davis, 2016]. В. Арена, опираясь на источники 50-х гг. до н. э. - 30-х гг. н. э. (при этом вовсе проигнорировав произведения поэтов), выделила три концепции свободы, характерные для того времени: 1) свобода как отсутствие правовых стеснений частной жизни римлян; 2) свобода как ограничение, основанное на верховенстве закона, тех действий граждан, которые препятствуют достижению общего блага; 3) свобода как отсутствие какого-либо господства [Arena, 2011, p. 482].

Сказанное позволяет считать анализ терминов «liber» и «libertas» в произведениях Горация актуальной исследовательской задачей. Научная интерпретация содержательного наполнения категории «свобода» у поэта способствует лучшему пониманию его политических взглядов, оцениваемых неоднозначно и современными специалистами [La Bua, 2013, p. 265-266]. Ведь если Гораций, в прошлом сторонник Марка Брута (Suet. Poet. Hor. 1), использовал «libertas» в том значении, которое ей придавали представители нобилитета ${ }^{6}$, то, веро-

3 Традиционным является отношение исследователей XIX-XX вв. к поэтам второй половины I в. до н. э. как к проводникам идей Августа [Ростовцев, 2000, с. 57-58; Syme, 1939, p. 253, 318, 412, 464]. В современной историографии такая позиция считается устаревшей [Галински, 2017].

${ }^{4}$ О популярности поэзии в эпоху Августа см.: [Гаспаров, 2018, с. 75-76].

5 По мнению ученого, поначалу (в конце 30-х - начале 20-х гг. до н. э.) Гораций симпатизировал Октавиану, но в конце 20-х гг. до н. э. поэт резко охладел к нему [Starr, 1969, p. 60, 64]. К противоположным выводам пришел Э.Т. Салмон [Salmon, 1946-1947, p. 9-13].

6 Брут стремился заявить о себе как об амбициозном представителе аристократического рода и в 44-43 гг. до н. э., полемизируя с Антонием и Октавианом посредством монетной чеканки, преподносил libertas как конкурентное преимущество лагеря республиканцев [Жаровская, 2009, с. 11-13]. 
ятно, он был склонен к оппозиционным взглядам, а также обладал высокой степенью независимости от воли принцепса.

При обращении к указанному вопросу необходимо учитывать, какой смысл в категорию «libertas» вкладывался в I в. до н. э. - до установления власти Октавиана. Хорошо известно, что в эпоху Поздней Республики «libertas» была важным лозунгом различных противоборствующих политических партий (partes) и группировок (factiones). По словам В.О. Любимовой [Любимова, 2015, с. 206], проблемы, связанные с политико-идеологической борьбой на закате Республики по-прежнему вызывают дискуссии среди исследователей; при этом в современной историографии трудно выделить какую-либо ведущую концепцию по данному вопросу. Согласно наблюдениям Н.Н. Трухиной [Трухина, 2017, с. 76, 81-84, 86-88], в это время существовали три политические «партии»: партия нобилитета, отстаивавшая традиционную систему управления государством, и две противостоявшие ей силы - фронда boni, состоявшая из средних слоев Италии (всадников и большинства сената), и мелкоплебейская партия populares, представленная отдельными политическими деятелями, которые апеллировали к массе простого народа. Однако многие историки продолжают следовать традиционному делению политических течений I в. до н. э. на optimates (отождествляемых с частью нобилей) и populares [Токарев, 2007, с. 134-139; Yakobson, 2016] ${ }^{7}$.

По представлениям optimates (т. е. большинства нобилей), свобода - это совокупность политических прав знати, подразумевающая возможность определяющего влияния на управление государственными делами [Токарев, 2011, с. 62 ${ }^{8}$; optimates, согласно их позиции, должны были охранять такой порядок от посягательств со стороны populares, стремящихся подавить свободу и установить regnum [Утченко, 1965, с. 171]. Populares, в свою очередь, понимали под libertas политические права плебса: возможность принимать законы и избирать магистратов [Токарев, 2011, с. 72]. На их взгляд, современный им политический порядок нельзя считать свободным, поскольку власть сосредоточена в руках группировки нобилей, руководствующихся своими узкими интересами; против такого положения дел «популяры» и призывали бороться [Утченко, 1965, с. 171]. Если принять концепцию Н.Н. Трухиной $[2017$, с. 84] о существовании третьей силы - партии «порядочных» - и признать в Цицероне ее идеолога, то, по всей видимости, свобода для данного политического течения должна была означать залог стабильного функционирования власти boni [Павлов, 2002, с. 37-38] ${ }^{9}$ и борьбу против политического засилья аристократии.

Подобные идеологические представления Поздней Республики не могли не оказать влияния на понимание libertas в эпоху Августа. Как убедительно показал А.Н. Токарев [Токарев, 2011, с. 150-155], в ходе борьбы за власть Октавиан, прибегнув к «популярской» трактовке категории «свобода», в то же время начал наполнять ее новым содержанием, в результате чего понятие «libertas» оказалось созвучным терминам «рах» (мир) и «securitas» (безопасность). Попытку выйти за рамки «узкопартийного» понимания свободы исследователь обнаруживает уже в трудах Саллюстия, заключая, что в это время libertas постепенно теряла свое политическое значение [Токарев, 2006, с. 9-10]. По мнению K. Раафлауба [Raaflaub, 2009, p. 154], понятие «libertas» не играло заметной роли в идеологической программе Августа. Той же позиции придерживается Я.Ю. Межерицкий [Межерицкий, 2016, с. 492-493], подчеркивающий, что случаи употребления Августом понятия «libertas» относятся к освобождению от внешних врагов государства. К. Галински [Галински, 2006, р. 3, 6-7], хотя и считает категорию «свобода» центральной для идеологиче-

${ }^{7}$ По авторитетному мнению Х. Виршубски, термин «оptimates» являлся самоназванием правящей римской олигархии - нобилитета [Wirszubski, 1968, p. 39]. С этой позицией не согласна Н.Н. Трухина [Трухина, 2017, с. 77].

8 Э. Фантам, ссылаясь на Х. Виршубски, говорила о целом сенаторском классе (вместо optimates или нобилей) [Fantham, 2005, p. 29].

9 Хотя А.А. Павлов, называя libertas Цицерона консервативной и статичной, судя по всему, отождествляет boni c optimates и представителями нобилитета. 
ской политики Августа, также отмечает, что libertas понималась уже не столько как свобода действий в политической сфере, сколько как свобода от внешних вторжений и угнетения (interference and oppression) - т. е. как securitas. Кажется неслучайным, что именно на время правления династии Юлиев-Клавдиев приходится становление религиозного культа Securitas и начало активного почитания безопасности как важного коллективного блага [Данилов, 2017, с. 82]. Гораций писал, что ему не страшна никакая смута (tumultus), пока всей землей владеет (teneo) Август (Hor. Od. III. 14. 14-16) ${ }^{10}$.

Первое, на что стоит обратить внимание, переходя к анализу произведений Горация, - поэт довольно редко использует термин «libertas»: всего 5 случаев употребления. Гораздо чаще встречается прилагательное «liber»: 24 раза. Приведенные цифры, конечно, несопоставимы с частотой обращения к понятию «libertas» Цицероном ${ }^{11}$ и Ливием ${ }^{12}$. Однако нужно учитывать, что перед нами не политические, философские или исторические трактаты, а поэтические произведения, рассчитанные на самую широкую аудиторию.

В «Эподах» и «Сатирах» ${ }^{13}$ «liber» ${ }^{14}$ и «libertas» ${ }^{15}$ употребляются в тесной связи с четырьмя темами: пороки и их осуждение, дружба, опьянение, «свобода слова»; и означают обилие, свободу от пороков и внешних обстоятельств (независимость), откровенность, развязность и возможность высмеивать чужие пороки. Прохожие полны негодования (liberrima indignatio) от вида гордого вольноотпущенника, выставляющего напоказ свои богатства (Epod. IV . 5-10). Вино развязывает язык и обнажает чувства, позволяя свободной желчи (libera bilis) бурлить в груди (Epod. XI. 13-16). Опьяненные гости допускают излишнюю вольность (maledicunt liberius - буквально «свободнее/обильнее злословят»), что пробуждает у хозяина страх (Sat. II. 8. 35-37). В то же время, стоит насмешливому гостю выпить вина, как он тут же становится comis (ласковым, любезным), urbanus (утонченным, учтивым) и liber (свободным, откровенным) (Sat. I. 4. 89-90).

Известно, что Гораций с теплотой относился к дружбе (amicitia) и высоко ценил ее роль в жизни человека (Sat. I. 5. 44) [Hunter, 1985, p. 480]. В «Посланиях» поэт противопоставляет друга (liberrimus Lollius - «свободнейший Лоллий») шуту (scurra) и блуднице (meretrix), равных в своей неверности (infidus) и льстивом раболепии (Ep. 1. 18. 1-4). Анализируя «Эподы» и «Сатиры», можно заметить, что образ liber amicus в некотором отношении близок к образу liber sapiens. Многочисленные пороки, характерные для обычных людей, не свойственны свободному мудрецу ${ }^{16}$, полностью владеющему собой, довольствующемуся малым и независимому от внешних волнений (Sat. II. 7. 83-84) ${ }^{17}$. Свободный друг, подобно мудрецу, способен излечить Горация от пороков и недостатков (vitia Sat. I. 4. 129-132). Более того, помощь liber amicus стоит в одном ряду с уроками pater (отца), приучившего Горация с юных лет замечать чужие пороки и самому избегать их, живя умеренно и бережливо (Sat. I. 4. 105-109). В другом месте поэт напрямую сравнивает отношения между друзьями и отношения между отцом и сыном, заявляя, что друзья должны с терпением относиться к недостаткам друг друга, подобно тому, как отец относится к недостаткам сына (Sat. I. 3. 43-44). Таким образом, мы можем утверждать, что, используя выражение «liber amicus», Гораций в определенном смысле синтезирует мудрость предков и возвышенность мудрецов, придавая понятию «libertas» философский и нравоучитель-

10 ...ego nec tumultum / nec mori per vim metuam tenente / Caesare terras.

${ }^{11}$ Около 388 раз [Павлов, 2003, с. 33].

12331 раз - при учете, что сохранилась лишь четверть его книг [Павлов, 2009, с. 213-214].

13 «Эподы» и «Сатиры», ранние произведения Горация, были написаны в 30-е гг. до н. э. [Тронский, 1988, c. 369-370].

${ }^{14}$ Встречается 11 раз.

15 Встречается 1 раз.

${ }^{16}$ Без сомнений, речь идет о мудреце стоического толка.

${ }^{17}$ Quisnam igitur liber? sapiens sibi qui imperiosus / quem neque pauperies neque mors neque vincula terrent... В похожем значении Гораций использует прилагательное «solutus», выражающее свободу от аmbitio (Sat. I. 6. 129) - тщеславия. 
ный оттенок ${ }^{18}$. Это обстоятельство свидетельствует о том, что в эпоху Августа существовала тесная взаимосвязь между стремлением восстановить mores maiorum и философскими этическими учениями, способствующими этому на ином уровне ${ }^{19}$.

Римляне не имели специального термина для обозначения «свободы слова»

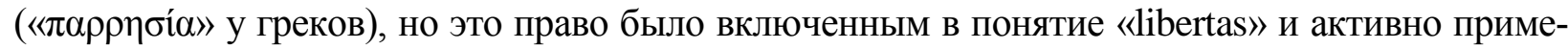
нялось руководящим слоем [Bowditch, 1994, p. 414-415]. Гораций два раза использует «libertas» в данном значении, но не в политической, а в социальной коннотации. Приводя в пример греческих комедиографов, поэт говорит о libertas как о возможности открыто высмеивать людей за их пороки, оправдывая свою вольность привычкой, воспитанной отцом (Sat. I. 4. 1-5, 103-106). Несколько иной оттенок «libertas» мы видим в позднем произведении «Науке поэзии». Гораций пишет, что в былые времена комедия была почитаема, но затем, впав в libertas (sed in vitium libertas excidit - Ars. 282), стала преступать закон (lex), который в итоге принудил хор к молчанию (Ars. 281-284). В данном контексте «свобода слова» приобретает негативную коннотацию и преподносится, скорее, как licentia - своеволие, дерзость, наглость ${ }^{20}$.

Интересно, что молодой Гораций, открыто симпатизирующий эпикурейской философии (Sat. I. 2. 73-79; I. 3. 95-98; I. 5. 100-103; II. 2. 36-37; II. 3. 199-223; II. 6. 60-62) ${ }^{21}$, воспринимает законы (iura) как силу, стремящуюся ликвидировать человеческий страх перед возможными опасностями (Sat. I. 3. 111), т. е. как благо. Законы (leges) ${ }^{22}$, как пишет поэт, возникнув из стремления прекратить бесконечные войны всех против всех, были направлены против воров, разбойников и любодеев (Sat. I. 3. 99-106). Знаменитый эпикуреец Лукреций, в свою очередь, рассматривает появление законов как причину зарождения всех человеческих страхов - прежде всего, перед наказанием (Lucr. 1147-1151). Следовательно, согласно эпикурейской философии, с возникновением первых законов человек утрачивает свою libertas, понимаемую как свободу от всяческих страхов (Cic. Nat. Deor. I. $56)^{23}$, а также как отсутствие страданий тела и души (D. L. X. 131) ${ }^{24}$. Исходя из вышесказанного, можно предположить, что в восприятии Горацием природы законов проявилось нарождавшееся в коллективном сознании римлян отношение к libertas как к securitas. Heсмотря на свои эпикурейские взгляды, поэт не видел в законах ничего негативного, что могло бы ограничить человеческую свободу. Для Горация законы - это положительное явление, призванное установить порядок и обуздать силы хаоса, т. е. обеспечить безопасность граждан. Неслучайно в одной из од победа Августа над беспорядком гражданских войн уподобляется победе Юпитера над хаосом бунтующих гигантов (Od. III. 4. 38-48).

В 23 г. до н. э. были изданы три книги од (Carmina), где встречается всего лишь три случая употребления слова «liber» (Od. I. 37; III. 5. 21-22; III. 24. 12-13). Наиболее интересно употребление Горацием понятия «liber» в контексте 37-й оды I книги. Данная ода была написана в 30 г. до н. э. как реакция на окончательное поражение Антония. При этом в центре внимания произведения - фигура Клеопатры, которую Гораций называет роковым чудовищем (fatale monstrum - Od. I. 37. 21) и безумной царицей (regina demens - Od. I. 37. 7), посмевшей угрожать Капитолию крушением (Od. I. 37. 6-8). Следовательно, про-

${ }^{18}$ Однако мудрый совет друга (amicorum... libera consilia - Epod. ХІ. 25-26) не в силах высвободить поэта из пут безрассудного влечения к юноше Ликиску. Подобное подвластно лишь другой соразмерной страстной любви (ardor) к юноше или девушке (Epod. XI. 23-28). Следовательно, разумное начало, представленное в образе liber amicus, уступает страстям, которые поэт, по всей видимости, связывает с образом вольного Купидона (liber Cupido - Epod. XVII. 57).

19 Понтифик и академик Котта в произведении Цицерона говорит, что от философа он ждет рациональных доказательств (rationes) тому, чему учат предки одной лишь силой своего авторитета (Cic. Nat. Deor. III. 6).

${ }^{20}$ О разнице между libertas и licentia см.: [Braund, 2004, p. 409-410, 426-427].

21 Еще Г. Буасье отмечал, что «Гораций принадлежал к тем людям, которые в молодости были очарованы Лукрецием» [Буасье, 2018, с. 181].

22 По всей видимости, понятия «іura» и «leges» Гораций использует как синонимы.

${ }^{23}$ His terroribus ab Epicuro soluti et in libertatem vindicati...

${ }^{24} \ldots \tau$. 
тивник Августа - это внешний враг, а гражданская война с Антонием оборачивается войной против Египта и Клеопатры ${ }^{25}$. Теперь же, когда главная угроза Риму нейтрализована, Гораций призывает выпить вина, свободной ногой (pede libero) ударив оземь (Od. I. 37. $1-2)^{26}$. Впервые в творчестве Горация понятие «liber» появляется в контексте освобождения от внешней опасности. Конечно, нельзя судить однозначно о том, что поэт подразумевал под «liber pes». Вполне вероятно - особенно если учитывать контекст произведения и тот смысл, который Август вкладывал в категорию «libertas», - что выражение «свободная нога» означало свободу от ножных кандалов, символизирующих порабощение внешним захватчиком. Похожее выражение («libera vestigia» - «свободные следы/подошвы») Гораций использовал в «Посланиях», подразумевая под этим, что он никому не подражает и идет своим путем (Еp. I. 19. 21-23) ${ }^{27}$.

В 20 г. до н. э. вышла первая книга «Посланий». Понятия «liber» ${ }^{28}$ и «libertas» ${ }^{29}$ используются здесь исключительно в философском (преимущественно в стоическом) значении и, по словам Ч. Старра [Starr, 1969, p. 63], являются ключевыми в атаке поэта на материализм. Отказывая сельской грубости (asperitas agrestis) в праве считаться libertas или virtus, поэт ставит эти понятия в один ряд (Ep. I. 18. 6-8) ${ }^{30}$. Приравнивать свободу и доблесть было свойственно для стоического мировоззрения. Стоик Зенон считал, что быть

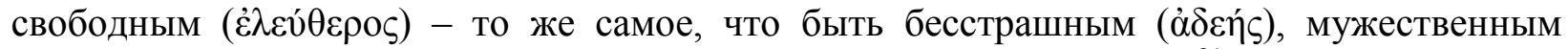

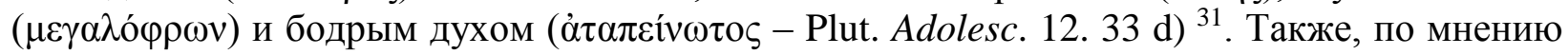
стоика, может считаться свободным (как гражданином, другом, домочадцем) только тот, кто стремится к добродетельному (D. L. VII. 33) ${ }^{32}$. Величайшим рабством (maxima servitus) Сенека Младший считал потребность в милости судьбы (Sen. V. beat. XV. 3) и учил жить настоящим (Sen. V. beat. XXVI. 3). Этот же суровый стоический ригоризм мы встречаем в отношении уже немолодого Горация к libertas ${ }^{33}$.

Высоко почитая свободу, поэт пишет, что liber sapiens - ниже только самого Юпитера (Ep. I. 1. 106-107). Быть свободным означает не склоняться под натиском Фортуны (Ep. I. 1. 68-69), не страшиться бедности (Еp. I. 10. 39-40; I. 16. 63-64) ${ }^{34}$, жить без страха (Ep. I. 16. 66) ${ }^{35}$, быть самодостаточным (Ep. I. 19. 21-23) - другими словами, быть независимым от внешних обстоятельств.

$\mathrm{B}$ «Науке поэзии», помимо уже приведенного нами значения «libertas» как «своеволие», мы встречаем выражения «libera vina» (Ars. 85) - обильные вина; «liber et ingenuus» (Ars. 383) - свободный и благородный (здесь понятие «liber» близко по значению к понятию «свободнорожденный»); и «liberque laborum rusticus» (Ars. 212-213) - свободный от дел крестьянин. В последнем случае libertas близка по значению к vacatio, в которой эпикурейцы обнаруживали залог счастливой жизни (Cic. Nat. Deor. I. 53).

В 17 г. до н. э. торжественно были проведены Вековые игры, знаменовавшие, по логике Августа, начало новой эры мирного процветания Рима. Вся церемония завершалась «Юбилейным гимном», написанным Горацием специально по запросу императора. В

${ }^{25}$ См. подробнее: [Lowrie, 2007, p. 82; Чисталев, 2014, с. 295].

${ }^{26}$ Nunc est bibendum, nunc pede libero / pulsanda tellus...

${ }^{27}$ Libera per vacuum posui vestigia princeps, / non aliena meo pressi pede. qui sibi fidet, / dux reget examen.

${ }^{28}$ Встречается 6 раз.

${ }^{29}$ Встречается 2 раза.

${ }^{30}$... asperitas agrestis... / dum volt libertas dici mera veraque virtus.

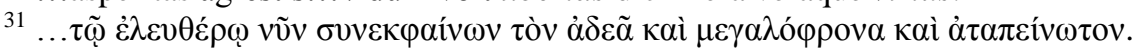

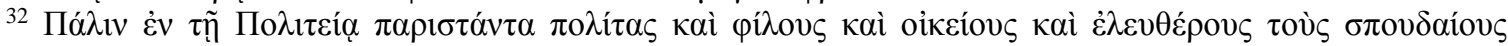
$\mu$ óvov...

33 Заметим, что стоическое и эпикурейское понимание свободы во многом пересекались. Этическая доктрина эпикуреизма была не менее требовательной к поведению человека, чем доктрина Стои, и, разумеется, она не сводилась к гедонизму, что признавал еще стоик Сенека (Sen. V. beat. XIII. 1). Поэтому философский эклектизм Горация в понимании свободы выглядит наиболее органичным.

${ }^{34} \mathrm{Sic}$ qui pauperiem veritus potiore metallis / libertate caret...

35 ...qui metuens vivet, liber mihi non erit umquam... 
одной из строчек, говоря об отступлении Энея из Трои, поэт использует выражение «liberum iter» (Carm. 43) - свободный путь. Троянцы смогли без вреда (sine fraude) покинуть родной город благодаря благочестивому Энею (Castus Aeneas), который защитил/укрепил/проложил (munivit) liberum iter (Carm. 37-44). Другими словами, троянцы отступили из Илиона по свободному (равно безопасному) пути, предоставленному Энеем, и только поэтому остались невредимыми. Понятие «liber» во второй раз за все творчество Горация приблизилось к значению «securus». Учитывая эпохальность и государственную значимость Вековых игр, мы полагаем, что подобное понимание свободы должно было соответствовать идеологической повестке режима Августа.

B IV книге од, созданной под очевидным давлением императора в последнее десятилетие жизни Горация (Suet. Poet. Hor. 5), когда поэт намеревался отойти от творчества и предаться философским раздумьям [Гаспаров, 2018, с. 297-299], всего один раз используется прилагательное «libera» (Od. IV. 14. 18). Данное понятие появляется в контексте прославления боевых заслуг военачальника Тиберия (maior Nero), разбившего избравших свободную смерть ретов (devota morti pectora liberae - Hor. Od. IV. 14. 14-18). Судя по контексту, mors libera выступает в роли альтернативы servitus варваров и не несет какойлибо политической нагрузки. При тех же обстоятельствах была создана II книга «Посланий», где мы вновь встречаем только одно упоминание категории «свобода» - в письме, адресованном самому Августу (Ep. II. 1. 147). Поэт использует «libertas» в контексте описания деревенского праздника, во время которого распевались шуточно-бранные песни фесценнины (Ep. II. 1. 139-146). Такую сельскую забаву Гораций и обозначает термином «libertas», в данном случае близким по значению слову «вольность». Нужно сказать, что столь редкое использование понятий «liber» и «libertas» в работах, созданных под непосредственным давлением со стороны власти, подтверждает выводы историков о незначительной роли концепта свободы в рамках идеологии принципата Августа.

Таким образом, в произведениях Горация нет ни одного использования понятий «liber» и «libertas» в том значении, которое в них вкладывали те или иные политические группировки I в. до н. э. В двух случаях «libertas» близка по смыслу к «securitas» (точнее: «liber» - к «securus»). В целом же доминируют социальная и философская коннотации понятия «свобода». Поэтому со всей уверенностью мы можем утверждать, что восприятие Горацием свободы находилось в русле идеологических установок принципата Августа и не несло в себе оппозиционных настроений. Философский акцент на независимости от внешних обстоятельств и довольстве малым должен был служить укреплению важного слагаемого римского мифа - идеализации бедности и осуждению богатства [Кнабе, 1994, с. 648]. Сделанные наблюдения также свидетельствуют о том, что в эпоху Принципата категория «libertas» теряет свое политическое значение.

\section{Список литературы}

1. Буасье Г. 2018. Римская религия во времена Августа. М., Вече, 416.

2. Галински К. 2017. Августовская литература и августовская «идеология»: пересмотр оценок. Шаги. Steps, 3 (4): 151-167.

3. Гаспаров М.Л. 2018. Гораций, или Золото середины. В кн.: Поэт и поэзия. М., РИПОЛ классик: 233-301.

4. Гаспаров М.Л. 2018. Поэт и поэзия в римской культуре. В кн.: Поэт и поэзия. М., РИПОЛ классик: 21-100.

5. Гуревич А.Я. 2007. Категории средневековой культуры. В кн.: Избранные труды. Средневековый мир. СПб., Изд-во СПбГУ: 17-260.

6. Данилов Е.С. 2017. Securitas в «Panegyrici Latini». Проблемы истории, филологии, культуры, 3 (57): 81-89.

7. Дементьева В.В. 2011. Римская «меритократия» и формирование принципа представительности (теоретико-историографический аспект). В кн.: Народ и демократия в древности: доклады российско-германской научной конференции. Ярославль, Изд-во ЯрГУ: 120-152. 
8. Дементьева В.В. 2010. Римская civitas республиканской эпохи. В кн.: Античная гражданская община: греческий полис и римская civitas. Ярославль, Изд-во ЯрГУ: 52-103.

9. Жаровская А.Н. 2009. Отражение политических идеалов Марка Юния Брута на монетах его чеканки. Проблемы истории, филологии, культуры, 3 (25): 9-16.

10. Кнабе Г.С. 1994. Рим Тита Ливия - образ, миф и история. В кн.: Тит Ливий. История Рима от основания города. Т. 3. М., Наука: 590-655.

11. Любимова О.В. 2015. Понятие «популяры» в современной историографии. Вестник древней истории, 1: 190-207.

12. Межерицкий Я.Ю. 2016. «Восстановленная республика» императора Августа. М., Русский фонд содействия образованию и науке, 992.

13. Павлов А.А. 2009. Свобода (libertas) в исторической концепции Тита Ливия. Диалог со временем, 27: 212-229.

14. Павлов А.А. 2003. Libertas у Цицерона: замечание к статистике и семантике понятия. Вестник Сыктывкарского университета, 5 (4): 31-41.

15. Ростовцев М.И. 2000. Общество и хозяйство в Римской империи. Т. 1. СПб., Наука, 400.

16. Токарев А.Н. 2007. Сравнительный анализ терминов «оptimates» и «boni» (к вопросу о политических группировках в эпоху Поздней Римской республики). Вісник Харківського національного університету імені В.Н. Каразіна, 762 (39): 130-143.

17. Токарев А.Н. 2011. Становление официальной идеологии принципата императора Августа. Харьков, Изд-во ХНУ, 268.

18. Токарев А.Н. 2006. Libertas у Саллюстия. Вісник Чернігівського державного педагогічного університету, 34 (4): 7-11.

19. Тронский И.М. 1988. История античной литературы. М., Высшая школа, 464.

20. Трухина Н.Н. 2017. Политика и политики «золотого века» Римской республики (II век до н. э.). СПб., Наука, 297.

21. Утченко С.Л. 1965. Кризис и падение Римской республики. М., Наука, 288.

22. Чисталев М.С. 2014. Антиегипетская политическая пропаганда Октавиана Августа в римской поэзии: образ Клеопатры как врага Рима. Вестник Нижегородского университета им. Н.И. Лобачевского, 1 (2): 293-300.

23. Anderson W.S. 1995. «Horatius Liber», Child and Freedman's Free Son. Arethusa, 28 (2/3): $151-164$.

24. Arena V. 2013. Libertas and the Practice of Politics in the Late Roman Republic. Cambridge, Cambridge University Press, 336.

25. Arena V. 2011. Roman sumptuary legislation: Three concepts of liberty. European Journal of Political Theory, 10 (4): 463-489.

26. Bowditch L. 1994. Horace's Poetics of Political Integrity: Epistle 1.18. The American Journal of Philology, 115 (3): 409-426.

27. Braund S.M. 2004. Libertas or Licentia? Freedom and Criticism in Roman Satire. In: I. Sluiter, R.M. Rosen (eds.), Free Speech in Classical Antiquity. Leiden - Boston, Brill: 409-428.

28. Davis P.J. 2016. Freedom of Speech in Virgil and Ovid. In.: P. Mitsis, I. Ziogas (eds.), Wordplay and Powerplay in Latin Poetry. Berlin - Boston, De Gruyter: 183-198.

29. Fantham E. 2005. Liberty and the People in Republican Rome. Transactions of the American Philological Association, 135 (2): 209-229.

30. Galinsky K. 2006. Vergil's Uses of «Libertas»: Texts and Contexts. Vergilius, 52: 3-19.

31. Hunter R.L. 1985. Horace on Friendship and Free Speech. Hermes, 113 (4): 480-490.

32. Johnston P.A. 2006. Turnus, Horses, and «Libertas». Vergilius, 52: 20-31.

33. La Bua B. 2013. Horace's East: Ethics and Politics. Harvard Studies in Classical Philology, 107: 265-296.

34. Lefèvre E. 1998. Vergil as a Republican (Aen. 6. 815-35). In: H.-P. Stahl (ed.), Vergils's Aeneid: Augustan Epic and Political Context. London, Duckworth in association with The Classical Press of Wales: $101-118$.

35. Lowrie M. 2007. Horace and Augustus. In: S. Harrison (ed.), The Cambridge Companion to Horace. Cambridge, Cambridge University Press: 77-90.

36. McGowan M.M. 2009. Ovid in Exile: Power and Poetic Redress in the Tristia and Epistulae ex Ponto. Leiden - Boston, Brill, 261. 
37. Raaflaub K. 2010. Between Tradition and Innovation: Shifts in Caesar's Political Propaganda and Self-Presentation. In: G. Urso (ed.), Cesare: Precursore o Visionario? Atti del convegno internazionale, Cividale del Friuli, 17-19 settembre 2009. Pisa, Edizioni ETS: 141-157.

38. Salmon E.T. 1946-1947. The Political Views of Horace. Phoenix 1 (2): 7-14.

39. Smith R.A. 2006. Books in Search of a Library: Ovid's «Response» to Augustan «Libertas». Vergilius, 52: 45-54.

40. Starr Ch.G. 1969. Horace and Augustus. The American Journal of Philology, 90: 58-64.

41. Syme R. 1939. The Roman Revolution. Oxford, Oxford University Press, 592.

42. Von der Osten D.E. 2006. The Cult of the Goddess «Libertas» in Rome and Its Reflection in Ovid's Poetry and Tibullan Love Elegy. Vergilius, 52: 32-44.

43. Wirszubski Ch. 1968. Libertas as a Political Idea at Rome during the Late Republic and Early Principate. Cambridge, Cambridge University Press, 196.

44. Yakobson A. 2016. optimates, populares. Available at: https://dx.doi.org/10.1093/acrefore/9780199381135.013.4578. (accessed 29 November 2019).

\section{References}

1. Boissier G. 2018. Rimskaya religiya vo vremena Avgusta [Roman religion in the Augustus' times]. Moscow, Veche, 416 (in Russian).

2. Galinsky K. 2017. Avgustovskaya literatura i avgustovskaya «ideologiya»: peresmotr ocenok [Augustan Literature and Augustan «Ideology»: an Ongoing Reassessment]. Shagi / Steps, 3 (4): 151-167.

3. Gasparov M.L. 2018. Goracij, ili zoloto serediny [Horace, the Gold of the Middle]. In: Poet i poeziya [Poet and poetry]. Moscow, RIPOL klassik: 233-301 (in Russian).

4. Gasparov M.L. 2018. Poet i poeziya v rimskoj kul'ture [Poet and Poetry in Roman Culture]. In: Poet i poeziya [Poet and poetry]. Moscow, RIPOL klassik: 21-100 (in Russian).

5. Gurevich A.Ya. 2007. Kategorii srednevekovoj kul'tury [Categories of Medieval Culture]. In: Izbrannye trudy. Srednevekovyy mir [Selected Works. The Medieval World]. Saint-Petersburg, SaintPetersburg State University Publishing House: 17-260 (in Russian).

6. Danilov E.S. 2017. Securitas in Panegyrici Latini. Problemy istorii, filologii, kul'tury [Journal of Historical, Philological and Cultural Stadies], 3 (57): 81-89 (in Russian).

7. Dementyeva V.V. 2011. Rimskaya «meritokratiya» i formirovanie principa predstavitel'nosti (teoretiko-istoriograficheskij aspekt) [Roman «Meritocracy» and the Formation of the Principle of Representativeness (Theoretical and Historiographic Aspect)]. In: Narod i demokratiya v drevnosti: doklady rossiysko-germanskoy nauchnoy konferentsii [The People and Democracy in Antiquity: Reports of the Russian-German Scientific Conference]. Yaroslavl, Yaroslavl State University Publishing House: 120-152 (in Russian).

8. Dementyeva V.V. 2010. Rimskaya civitas respublikanskoj epohi [Roman civitas of Republican period]. In: Antichnaya grazhdanskaya obshchina: grecheskiy polis i rimskaya civitas [Ancient Civil Community: the Greek polis and the Roman civitas]. Yaroslavl, Yaroslavl State University Publishing House: 52-103 (in Russian).

9. Zharovskaya A.N. 2009. Otrazhenie politicheskih idealov Marka Yuniya Bruta na monetah ego chekanki [Reflection of Political Ideals of Marcus Junius Brutus in his Coinage]. Problemy istorii, filologii, kul'tury [Journal of Historical, Philological and Cultural Stadies], 3 (25): 9-16 (in Russian).

10. Knabe G.S. 1994. Rim Tita Liviya - obraz, mif i istoriya [Rome of Titus Livy - Image, Myth and History]. In: Tit Liviy. Istoriya Rima ot osnovaniya goroda. T. 1 [Titus Livy. History of Rome from its Foundation]. Moscow, Nauka: 590-655 (in Russian).

11. Lyubimova O.V. 2015. Ponyatie «populyary» v sovremennoj istoriografii [The Concept of «Populares» in Modern Historiography]. Vestnik drevnej istorii [Journal of Ancient History], 1: 190-207 (in Russian).

12. Mezheritskiy, Ya.Yu. 2016. «Vosstanovlennaya respublika» imperatora Avgusta [Emperor Augustus' «Restored Republic»]. Moscow, Russian foundation for science and education, 992 (in Russian).

13. Pavlov A.A. 2009. Svoboda (libertas) v istoricheskoj koncepcii Tita Liviya [Liberty (libertas) in the Historical Concept of Titus Livy]. Dialog so vremenem [Dialogue with Time], 27: 212-229 (in Russian). 
14. Pavlov A.A. 2003. Libertas u Cicerona: zamechanie k statistike i semantike ponyatiya [Libertas in Cicero's works: A Remark on the Statistics and Semantics of the Concept]. Vestnik Syktyvkarskogo universiteta [Bulletin of Syktyvkar University], 5 (4): 31-41.

15. Rostovtsev M.I. 2000. Obshchestvo i khozyaystvo v Rimskoy imperii [The Social and Economic History of the Roman Empire]. T. 1. Saint-Petersburg, Nauka, 400 (in Russian).

16. Tokarev A.N. 2007. Sravnitel'nyj analiz terminov «optimates» $\mathrm{i}$ «boni» (k voprosu o politicheskih gruppirovkah v epohu Pozdnej Rimskoj respubliki) [The Comparative Analysis of the Terms «Optimates» and «Boni» (to the Question of Political Factions in the Late Roman Republic)]. Visnik Harkivs'kogo nacional'nogo universitetu imeni V.N. Karazina [The Journal of V.N. Karazin Kharkiv National University], 762 (39): 130-143 (in Russian).

17. Tokarev A.N. 2011. Stanovlenie ofitsial'noy ideologii printsipata imperatora Avgusta [Formation of the Official Ideology of the Emperor Augustus' Principate]. Kharkiv, Kharkiv National University Publishing House, 268 (in Russian).

18. Tokarev A.N. 2006. Libertas u Sallyustiya [Libertas in Sallust's works]. Visnik Chernigivs'kogo derzhavnogo pedagogichnogo universitetu [Bulletin of Chernihiv National Pedagogical University], 34 (4): 7-11 (in Russian).

19. Tronskiy I.M. 1988. Istoriya antichnoy literatury [History of Ancient Literature]. Moscow, Vysshaja shkola, 464 (in Russian).

20. Trukhina N.N. 2017. Politika i politiki «zolotogo veka» Rimskoy respubliki (II vek do n. e.) [Policy and Politicians of the «Golden Age» of the Roman Republic (II century BC)]. Saint-Petersburg, Nauka, 297 (in Russian).

21. Utchenko S.L. 1965. Krizis i padenie Rimskoy respubliki [The Crisis and Fall of the Roman Republic]. Moscow, Nauka, 288 (in Russian).

22. Chistalev M.S. 2014. Antiegipetskaya politicheskaya propaganda Oktaviana Avgusta v rimskoj poezii: obraz Kleopatry kak vraga Rima [Octavian's Political Propaganda in Roman Poetry: the Image of Cleopatra as an Enemy of Rome]. Vestnik Nizhegorodskogo universiteta im. N.I. Lobachevskogo [Vestnik of Lobachevsky University of Nizhni Novgorod], 1 (2): 293-300 (in Russian).

\section{ИНФОРМАЦИЯ ОБ АВТОРЕ}

Усов Дмитрий Андреевич, магистрант кафедры всеобщей истории Ярославского государственного университета им. П.Г. Демидова

\section{INFORMATION ABOUT THE AUTHOR}

Dmitry A. Usov, master student of the Department of General History, P.G. Demidov Yaroslavl State University, Yaroslavl, Russia 